\title{
The Study of Estrous Cycle Phases Female Rats With the Use of N-Acetylcysteine in Ovarian Graft
}

\section{Estudo do Ciclo Estral de Ratas com Uso de N-Acetilcisteína no Enxerto Ovariano}

\author{
Maria Clara da Silva Durando*a; Elivânia de Amorim Marques Gomes ${ }^{\text {ab; }}$ Edna Frasson de Souza Monteroc

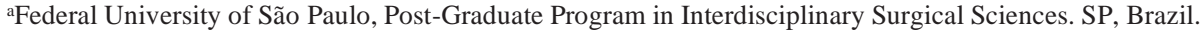 \\ ${ }^{b}$ Federal University of Vale do Sao Francisco. PE, Brazil \\ ${ }^{c}$ University of São Paulo, Faculty of Medicine, Department of Surgery, Laboratory of Surgical Physiopathology (LIM-62). SP, Brazil. \\ *E-mail: claradurando@gmail.com \\ Recebido em: 06/08/2020 \\ Aprovado em: 24/11/2020
}

\begin{abstract}
Ovarian graft may be the target of the biochemical effects of oxidative stress caused at the time of transplantation. In order to evaluate the effect of $\mathrm{N}$-acetylcysteine on the ovarian graft, regarding the estrous cycle preservation, 50 female and virgin EPM-1 Wistar rats, weighing up to $250 \mathrm{~g}$, originating from CEDEME of UNIFESP, were kept in adequate sanitary conditions. receiving their own food and water. Daily vaginal smears were performed to identify the estrous phase for 8 days. The animals were randomly distributed into 05 groups: 1st Group (GTx), saline was administered subcutaneously, 2nd (NAC 150mgKg), 3rd (NAC 300mg / Kg), 4th (NAC 600 mg / Kg) and 5th (NAC 1200mg / Kg), that were administered NAC subcutaneously on the abdominal face, 60 minutes before left unilateral ovarian transplantation in retroperitoneum and contralateral oophorectomy for purposes of histomorphological analysis, with colpocytological evaluation. Euthanasia was performed by means of anesthetic lethal dose in half of the animals on the $4^{\text {th }}$ postoperative day, with a single vaginal smear collection and euthanasia on the rest of the animals, between the $14^{\text {th }}$ and $16^{\text {th }}$ days, after the material was collected in order to define the estrus phase. It was evaluated inthe graft that the animals exhibited in all groups return of estrous cycle in the later phase of the post-transplant, with better definition of regular cycle in the highest dosages of $\mathrm{N}$-acetylcysteine. $\mathrm{N}$-acetylcysteine induced the return of the estrous cycle in the rats' ovarian graft, mainly in the highest dosage, proving its effectiveness in revascularization of the tissue after ischemia and reperfusion.
\end{abstract}

Keywords: Acetylcysteine. Reperfusion. Histocompatibility Antigens. Menstrual Cycle.

\section{Resumo}

O enxerto ovariano pode ser alvo dos efeitos bioquímicos do stress oxidativo causado no momento do transplante. Com o objetivo de avaliar o efeito da $\mathrm{N}$-acetilcisteína no enxerto ovariano, quanto à preservação do ciclo estral, foram utilizados 50 ratos EPM-1 Wistar, fêmeas e virgens, pesando até $250 \mathrm{~g}$, originários do CEDEME da UNIFESP, mantidos em adequadas condições sanitárias, recebendo ração própria e água. Realizados esfregaços vaginais diários para identificação da fase estral durante 08 dias. Os animais foram distribuídos aleatoriamente em 05 grupos: $1^{\circ}$ Grupo (GTX), administrada solução salina via subcutânea, $2^{\circ}(\mathrm{NAC} 150 \mathrm{mg} \mathrm{Kg}), 3^{\circ}(\mathrm{NAC} 300 \mathrm{mg} / \mathrm{Kg}), 4^{\circ}(\mathrm{NAC} 600 \mathrm{mg} / \mathrm{Kg})$ e $5^{\circ}(\mathrm{NAC}$ $1200 \mathrm{mg} / \mathrm{Kg}$ ), aos quais foi administrada NAC por via subcutânea em face abdominal, 60 minutos antes do transplante unilateral esquerdo do ovário em retroperitônio e à ooforectomia contra-lateral para fins de análise histomorfológica, com avaliação colpocitológica. A eutanásia foi realizada por meio da dose letal do anestésico em metade dos animais no $4^{o}$ dia de pós-operatório, realizado única coleta de esfregaço vaginal e a eutanásia no restante dos animais, entre o $14^{\circ}$ e $16^{\circ}$ dia, após a coleta do material para definição da fase estro. Foi avaliado no enxerto que os animais apresentaram em todos os grupos retorno de ciclo estral na fase mais tardia do pós-transplante, com melhor definição de ciclo regular nas dosagens mais elevadas de N-acetilcisteína. A N-acetilcisteína induziu o retorno do ciclo estral no enxerto ovariano de ratas, principalmente na maior dosagem comprovando sua eficácia na revascularização do tecido após isquemia e reperfusão.

Palavras-chave: Acetilcisteína. Reperfusão. Transplante. Ciclo Ovariano.

\section{Introduction}

In an attempt to preserve the endocrine function, ovarian transplantation is a good alternative for those women of reproductive age who have undergone cy'totoxic treatments ${ }^{1,2}$. Radiotherapy and chemotherapy may affect the ovarian function, even when the ovaries are not treated ${ }^{3,4}$.

According to Marcondes et al. ${ }^{5}$, the female rats' estrous cycle is determined in four phases, proestrus, estrus, metestrus and diestrus, from which the cellular types were defined, respectively, observed in the rats' vaginal smear. Due to ischemia and reperfusion injury at the time of transplantation, there are already studies showing loss of up to $50 \%$ of ovarian follicles after transplantation ${ }^{6}$.

Several experimental studies have demonstrated the drugs efficacy use to prevent or attenuate ischemia and reperfusion injuries, such as the use of superoxide dismutase, catalase, mannitol, allopurinol, vitamin $\mathrm{E}$ and $\mathrm{N}$-acetylcysteine $\mathrm{e}^{7-9}$.

Ischemia and reperfusion injury caused at the time of transplantation are also associated with inflammation, cytokine production and increased expression of adhesion molecules by hypoxic endothelial cells recruiting polymorphonuclear leukocytes to the reperfused tissue $\mathrm{e}^{10,11}$. Therefore, the oxidative stress that occurred at the time of transplantation results in an 
increase in free radicals and a decrease in proliferative activity as a result.

Ovarian transplantation for its functionality only requires that the implant site be close to a large vascular network, so that neoangiogenesis occurs, constituting the avascular heterotopic transplant, a technique already well known by literature and with satisfactory results ${ }^{12}$.

Study with ovarian autologous implantation in the main motor showed viability with regular cycle return, obtaining better morpho functional preservation with the slices implantation ${ }^{13}$.

$\mathrm{N}$-acetylcysteine, in turn, is considered a precursor of GSH due to its chemical model providing radical sulfhydryl reactive oxygen species and has already been studied with good perspective in some studies to prevent IR injury ${ }^{14-16}$.

The objective of this experiment is to evaluate the quality of the ovarian graft with the use of $\mathrm{N}$-acetylcysteine, in terms of preservation of the female rats' estrous cycle.

\section{Material and Methods}

After the evaluation and approval by the Ethics Committee in Research, in animal experimentation, of the Federal University of the State of São Paulo (UNIFESP), with CEP no. $1737 / 11$ for use with animals, 50 rats, EPM- 1 Wistar lineage, females, virgins, aged between 03 and 04 months were used, weighing about 250 grams. The animals were supplied by Centro de Desenvolvimento de Modelos de Animais de Experimentação (CEDEME) of UNIFESP-EPM, kept grouped in appropriate boxes with controlled temperature and light, and water and food ad libitum.

The sample was randomly distributed in four groups of 10 animals each, one control group and the groups of the experiment according to the applied dose of $\mathrm{N}$-acetylcysteine per mg/kg, respectively, NAC 150, NAC 300, NAC 600, NAC 1200. All animals were submitted to daily vaginal smears, 08 days before transplantation to determine diestrus, a phase established to perform transplantation.

The animals in both groups were anesthetized with ketamine hydrochloride at a dose of $60 \mathrm{mg} . \mathrm{kg}^{-1}$ and xylazine hydrochloride at a dose of $10 \mathrm{mg} . \mathrm{kg}^{-1}$ by intramuscular use on the lateral face of the right rear paw. With the adequate anesthetic plane, epilation and antisepsis of the abdominal region were performed, followed by subcutaneous NAC administration, half applied to each hypochondrium, in the median abdomen line.

After 60 minutes of absorption, laparotomy of the abdominal-pelvic cavity was performed in the median line and fat dissection was performed to identify the uterine and ovary horns, followed by the ovaries bilateral removal at the junction of the uterine horns. The right ovary was immediately placed in $10 \%$ buffered formaldehyde solution for the pathologies exclusion. The left ovary, also intact, was immediately reimplanted in the retroperitoneum by means of a stitch with nylon 6-0 wire, close to the great vessels, without vascular anastomosis.

According to the postoperative periods, the $4^{\text {th }}$ and $14^{\text {th }}$ days, the animals were euthanized with lethal dose of anesthetic. In the post-transplant period, 5 animals from each group were randomly subjected to the single collection of vaginal smears on the $4^{\text {th }}$ postoperative day, in order to define the estrous phase and then subjected to euthanasia. The remaining animals from each group were collected daily on the following days, from the $10^{\text {th }}$ day, until the estrus phase or proestrus phase of the estrous cycle was detected, being considered the $14^{\text {th }}$ post-transplant day of euthanasia.

\section{Results and Discussion}

In the groups tested, whether on the $4^{\text {th }}$ or $14^{\text {th }}$ day ofposttransplantation, it was observed that the colpocytological examination reveals the presence of a new cycle beginning with the passage through the diestrus phase.

The proestrus presented predominance of nucleated and anucleated epithelial cells, followed by estrus, characterized by the presence of cornified or keratinized cells. In the metaestrus, in addition to the cells in the two previous phases, the presence of leukocytes was observed.

The smears on the $14^{\text {th }}$ day show the presence of a new diestrus, characterized by the scarcity of cellular elements and a great concentration of leukocytes and mucus, confirming the return of the estrous cycle after transplantation.

The four stages of the estrous cycle cited by Marcondes (2002) were observed in both groups. The results obtained in the present study show that the use of $\mathrm{N}$-acetylcysteine, at the highest dosage $-1200 \mathrm{mg} / \mathrm{kg}$, contributed to the return of cyclicity, which was confirmed in the later period of posttransplantation. A table is followed bellow, with the stages of estrus in the groups of females rats used, Control and dosages of $\mathrm{N}$-acetylcysteine, with analysis of the swabs of the estrus cycle on day 4 and on day 14 post-transplant days.

Table 1 - Stages of the estrous cycle of vaginal smear on the $4^{\text {th }}$ and $14^{\text {th }}$ day of post-transplantation

\begin{tabular}{|c|c|c|c|c|}
\hline \multirow{2}{*}{$\begin{array}{c}\text { Group of } \\
\text { female Rats }\end{array}$} & \multicolumn{2}{|c|}{ Estrus stages - 4 } & Day & \multicolumn{2}{c|}{ Final Cycle - 14 } & th Day \\
\cline { 2 - 5 } & Phase D & $\begin{array}{c}\text { Phase P, E } \\
\text { or M }\end{array}$ & R Cycle & I Cycle \\
\hline GTx & $66.7 \%(2)$ & $33.3 \%(1)$ & $33.3 \%(2)$ & $66.7 \%(4)$ \\
\hline NAC 150 & $75 \%(3)$ & $25 \%(1)$ & $50 \%(3)$ & $50 \%(3)$ \\
\hline NAC 300 & $100 \%(4)$ & $0 \%(0)$ & $50 \%(3)$ & $50 \%(3)$ \\
\hline NAC 600 & $33.3 \%(1)$ & $66.7 \%(2)$ & $83.3 \%(5)$ & $16.7 \%(1)$ \\
\hline NAC 1200 & $40 \%(2)$ & $60 \%(3)$ & $100 \%(5)$ & $0 \%(0)$ \\
\hline
\end{tabular}

*Independence test (Fisher's Exact Test). Test Hypotheses: Ho:there is independence between group and variable. HA:there is association between group and variable. Value $p=0.745\left(4^{\text {th }} \mathrm{DAY}\right)$. Value $\mathrm{p}=0.149\left(14^{\text {th }}\right.$ DAY).

Source: Research data

In order to maintain the gonads functionality and their physiology, heterotrophic ovarian autologous implant has been proposed in many studies. However, the relevant 
question to consider ovarian autrotransplantation as a promising alternative is to ensure the reduction of the harmful effects caused by ischemia and reperfusion.

There are several strategies in the transplantation of avascular heterotopic ovary developed with the objective of minimizing the loss of number of follicles, due to the of $\mathrm{I} / \mathrm{R}$ injury, since about half of the primordial follicles are lost in initial ischemia, persisting until the beginning of neoangiogenesis ${ }^{17}$.

Study with ovarian transplantation in inguinal region in rats, both with avascular autologous implant, showed to be promising in order to preserve the ovarians vitality ${ }^{18}$.

In view of the fact that the surgical removal of an organ itself results in injury due to ischemia, studies also showed that the influx of oxygen into the ischemic tissue would lead to a series of biochemical and cellular alterations mediated mainly by the formation of oxygen free radicals ${ }^{19}$. Therefore, ischemia and reperfusion injury are the main cause of massive failure of ovarian follicles during transplantation ${ }^{20}$.

An analysis of the estrous cycle of rats after the autologous ovarian transplant will contribute as an initial step to evaluate the return of graft functionality. Because of the short duration of their estrous cycle, female rats constitute a good model for the study of the alterations that occur during the reproductive cycle $^{21}$.

According to studies using NAC, in different posologies and showing that it is effective on the I/R injury in organs such as kidney, liver, lung, fasciocutaneous flap and ovary 22,23 , NAC was chosen for the present study.

In the present study, in all doses, the animals presented a regular cycle, showing a preservation of the follicles in relation to the ischemia involved in the transplant process, with total cycle regularity in the group where higher dose of NAC was administered

$\mathrm{N}$-acetylcysteine is targeted at mitochondria, in which the respiratory chain is processed, and has therefore been used in numerous clinical and experimental studies in order to make clear its role in modulating the activity of reactive oxygen species $^{24}$.

Damous et al (2009), studying the vaginal epithelium in the post-transplant period, evidenced on the $4^{\text {th }}$ and $7^{\text {th }}$ day a non-keratinized squamous epithelium, and on the $14^{\text {th }}$ and $21^{\text {st }}$ day a squamous and keratinized epithelium, with maintenance of the estrogenic activity and at the end of 21 days in maximum activity $^{25}$.

The research with remote ischemic preconditioning corroborates the current research to attenuate the ischemia and reperfusion injury, ensuring the return of gland functionality, since it shows a tendency to restart early in the estrus cycle ${ }^{26}$.

Petroianu et al. ${ }^{27}$ during a 10-day evaluation period between 3 and 6 months of heterotrophic transplantation, reported inadequate ovarian function in the transplanted group, in animals that remained in irregular cycles or diestrus. According to Weissman et al. animals subjected to heterotrophic transplantation in subcutaneous tissue began their estrous cycle on the $9^{\text {th }}$ PO Day ${ }^{28}$. In the current study, estrus was identified in groups with higher levels of NAC and in the later period with greater ease.

In the colpocytological evaluation of smears in the transplanted rats, the diestrus corresponding to the initial action of estradiol on the organism did not present significance in relation to the Control group on the 4th day, however, it showed in the next phases of the estrous cycle a significant presence in the dosages 600 and $1200 \mathrm{mg} / \mathrm{kg}$.

$\mathrm{N}$-acetylcysteine has shown a beneficial effect on the cyclicity preservation of the transplanted female rats, revealing an attenuation in the ischemia injury and reperfusion of the ovarian graft. Studies with later postoperative period should contribute to confirm this effect in the long term.

The results showed that in the later phase of posttransplantation, all groups presented an estrous cycle with the use of NAC, as well as the massive presence of regular cycle at the highest dosage administered.

\section{Conclusion}

The use of $\mathrm{N}$-acetylcysteine in higher dosage provided for the return of regular estrous cycle in the ovarian graft of female rates, mainly at the highest dosage observed in later period of post-transplantation, proving its efficacy in the tissues revascularization after ischemia and reperfusion

\section{References}

1. Kutluk O, Erkan B. Ovarian transplantation in humans: indications, techniques and the risk of reseeding cancer. Eur J Obstet Gynecol Reprod Biol 2004:45-7. doi: 10.1016/j. ejogrb.2003.11.010

2. Barros FSV, Oliveira RM, Alves FMT, Sampaio M, Geber S. Successful ovarian autotransplant with no vascular reanastomosis in rats. Transplantation 2008:1628-30. doi: 10.1097/TP.0b013e31818c2948

3. Castro e Silva Jr. O, Centurion S, Pacheco EG, Brisotti JL, Oliveira AF, Sasso KD. Aspectos básicos da lesão de isquemia e reperfusão e do pré-condicionamento isquêmico. Acta Cir Bras 2002: 96-100. doi: https://doi.org/10.1590/ S0102-86502002000900020

4. Miranda LEC, Viaro F, Ceneviva R, Evora PRB. As bases experimentais da lesão por isquemia e reperfusão do fígado: revisão. Acta Cir Bras 2004:1-12. doi: https://doi.org/10.1590/ S0102-86502004000100001.

5. Marcondes FK, Bianchi FJ, Tanno AP. Determination of the estrous cycle phases of rats: some helpful considerations. Braz J Biol 2002:609-14. doi: https://doi.org/10.1590/S151969842002000400008

6. Meirow DN. The effects of radiotherapy and chemotherapy on female reproduction. Hum Reprod Update 2001:535-43. doi: 10.1093/humupd/7.6.535

7. Nugent D, Newton H, Gallivan L, Gosden RG. Protective effect of vitamin $\mathrm{E}$ on ischaemia-reperfusion injury in ovarian grafts. J Reprod Fertil 1998;341-6. doi: 10.1530/jrf.0.1140341

8. Gomes RZ, Romanek GMM, Przybycien M, Amaral DC, Akahane HGK. Evaluation of the effect of allopurinol 
as a protective factor in post ischemia and reperfusion inflammation in Wistar rats. Acta Cir Bras 2016:126-132. doi: https://doi.org/10.1590/S0102-865020160020000007.

9. Kim S, Kang HG, Lee HH, Ko SD, Gosden RG. Quantitative assessment of ischemic tissue damage in ovarian cortical tissue with or without antioxidant (ascorbic acid) treatment. Fertil Steril 2004;31:679-85. doi: 10.1016/j.fertnstert.2004.05.022.

10. Miranda LEC, Viaro F, Ceneviva R, Evora PRB. As bases experimentais da lesão por isquemia e reperfusão do fígado: revisão. Acta Cir Bras 2004:3-11. doi: https://doi.org/10.1590/ S0102-86502004000100001.

11. Barbosa KBF, Costa NMB, Alfenas RCG, De Paula SO, Minim VPR, Bressan J. Estresse oxidativo: conceito, implicações e fatores modulatórios. Rev Nutr 2010:629-43. doi: https://doi.org/10.1590/S1415-52732010000400013.

12. Alberti LR, Vasconcellos LS, Barbosa JF, Petroianu A. Implante autólogo ovariano no omento maior: estudo experimental. Rev Bras Ginecol Obstet 2002:187-92. doi: https://doi.org/10.1590/S0100-72032002000300007.

13. Khan AW, Fuller BJ, Shah SR, Davidson BR, Rolles K. A prospective randomized trial of $\mathrm{N}$-acetylcysteine administration during cold preservation of the donor liver for transplantation. Ann Hepatol 2005:121-6. doi: 10.1016/ S1665-2681(19)32075-7

14. Didoné EC, Cerski CT, Kalil AN. N-acetilcisteína diminui a congestão hepática na lesão de isquemia e reperfusão: estudo experimental. Rev Col Bras Cir 2000:1485-90. doi: https:// doi.org/10.1590/s0100-69912002000400002.

15. Salim CS, Montero EFS, Simões MJ, Abrahão MS, Ramalho CEB, Fagundes DJ. Efeito da N-acetilcisteína no pulmão após isquemia hepática em ratos. Acta Cir Bras 2002:177-80. doi: https://doi.org/10.1590/S0102-86502002000300005

16. Lee EJS, Silva SM, Simões MJ, Montero EFS. Effect of Nacetylcysteine in liver ischemia-reperfusion injury after $30 \%$ hepatectomy in mice. Acta Cir Bras 2012:346-9. doi: 10.1590/S0102-86502012000400011

17. Ceschin ÁP, Biondo-Simões MLP, Thomaz BAC, Totsugui J. Avaliação hormonal indireta e estudo da preservação folicular em tecido ovariano autólogo transplantado para região inguinal em ratos. Acta Cir Bras 2004:27-30. doi: https://doi. org/10.1590/S0102-86502004000100004.

18. Karlidag T, Yildiz M, Yalcin S, Colakoglu N, Kaygusuz I, Sapmaz E. Evaluation of the effect of methylprednisolone and $\mathrm{N}$-acetylcystein on anastomotic degeneration and regeneraton of the facial nerve. Auris Nasus Larynx 2012:145- 50. doi: 10.1016/j.anl.2011.03.004
19. Campos EBP, Yoshida WB. O papel dos radicais livres na fisiopatologia da isquemia e reperfusão em retalhos cutâneos: modelos experimentais e estratégias de tratamento. J Vasc Bras 2004;5:357-66.

20. Damous Luciana L. Efeito do precondicionamento isquêmico remoto no transplante autólogo de ovário fresco e criopreservado em ratas [Tese (Doutorado)]. [place unknown]: Universidade Federal de São Paulo (UNIFESP); 28/01/2009.

21. Marcondes FK, Bianchi FJ, Tanno AP. Determinação das fases do ciclo estral de ratos: algumas considerações úteis. Braz J Biol. 2002:609-14. doi: https://doi.org/10.1590/ S1519-69842002000400008.

22. Webster RS, Montero EFS, Fagundes DJ, Zettler CG, Coiro $\mathrm{J}$. The role of ischemic preconditioning at the gracilis muscle of rats in the early phase of reperfusion injury. Acta Cir Bras 2006:80-6. doi: 10.1590/s0102-86502006000200005

23. Masha A, Manieri C, Dinatale S, Bruno GA, Ghigo E, Martina V.Prolonged treatment with $\mathrm{N}$-acetylcysteine and L-arginine restores gonadal function in patients with polycystic ovary syndrome. J Endocrinol Invest 2009870-2. doi: 10.1007/ BF03345763

24. Andrade Júnior DR, Souza RB, Santos SA, Andrade Dahir Ramos de. Os radicais livres de oxigênio e as doenças pulmonares. J Bras Pneumol 2005:60-8. doi: https://doi. org/10.1590/S1806-37132005000100011.

25. Damous LL, Silva SM, Lopes RAM, Sakano CRSB, Simões MJ, Montero EFS. Study on the vaginal smear of rats submitted to autologous ovarian transplant: impact of remote ischemic preconditioning. Acta Cir Bras 2009:387-92. doi: https://doi.org/10.1590/S0102-86502009000500009

26. Yamaki VN, Gonçalves TB, Coelho JVB, Pontes RVS, Costa FLS, Brito MVH. Efeito protetor do per-condicionamento isquêmico remoto nas lesões da síndrome de isquemia e reperfusão renal em ratos. Rev Col Bras Cir 2012:529-33. doi: https://doi.org/10.1590/S0100-69912012000600014.

27. Petroianu A, Alberti LR, Vasconcellos LS. Avaliação póstransplante de ovários íntegros e fatiados sem anastomose vascular. Rev Assoc Med Brasil 2006:447-52. doi: https:// doi.org/10.1590/S0104-42302006000600027.

28. Weissman A, Gotlieb L, Colgan T, Jurisicova A, Greenblatt EM, Casper RF. Preliminary experience with subcutaneous human ovarian cortex transplantation in the NOD- SCID mouse. Biol Reprod. 1999:1462-7. doi: 10.1095/ biolreprod60.6.1462 